cided on July 28th that the State Legislature has no right to interfere with or dictate the management of the University of Michigan. The Legislature passed an act at its last session directing the regents to establish the homeopathic department of the University in Detroit. The regents refused to comply on the ground that the act was unconstitutional, and a mandamus was asked for to compel them to establish the department in Detroit. The Court holds that the regents have the sole control of the University and that the act of the Legislature is invalid.

Ground has been broken for the new science hall at Lake Erie Seminary, O. Of the $\$ 20,000$ required for the completion of the building, $\$ 14,000$ has already been raised. In addition $\$ 10,000$ has been subscribed for equipment.

DR. H. T. Lukens, of Clark University, has been appointed professor of education at Bryn Mawr College, and Dr. Colin A. Scott to the chair of experimental psychology and child study at the Chicago Normal School.

Mr. BEN F. HILL, B. S., has been appointed Fellow in Geology at the University of Texas. $\mathrm{He}$ will assist in the laboratory instruction in paleontology and mineralogy under the direction of Dr. F. W. Simonds.

Mrs. ARThur Jackson has contributed to the Sheffield Medical School the sum of $£ 5,000$ towards the endowment of a chair of anatomy, to be called the Arthur Jackson Chair of Anatomy. Mr. Jackson, who died recently, was much interested in the success of the Medical School, and had served it in the capacity of Secretary and Lecturer.

DR. J. Norman Collie, F.R.S., has been appointed professor of chemistry in the Pharmaceutical Society's School of Pharmacy. Dr. Collie has been for some time associated with Professor Ramsay in the teaching of chemistry at University College, London. The Council of Bedford College for Women, London, has appointed Dr. Thomas Morison Legge, to the professorship of hygiene.

AMong recent foreign appointments we note the following: Professor Valentiner, of Carlsruhe, has been called to the chair of astronomy in the University of Heidelberg. Professor A. B. Tichamerow has been appointed director of the Zoological Museum at Moscow. Professor Gutermuth, of Aachen, has been made professor of engineering in the technical high school at Darmstadt. Dr. Von Rümker, professor of agriculture in the University of Breslau, has been called to Leipzig. Dr. Henking, of the University of Göttingen, has been promoted to a professorship of zoology, and Dr. H. Biltz, of the University of Greifswald, to a professorship of chemistry. Dr. Schenk, of the University of Bonn, has been elected full professor of botany and director of the botanical gardens at the Technical High School at Darmstadt. Dr. Pauly, docent in the University at Munich, has been promoted to an assistant professorship of applied geometry, and Dr. W. Semmler, of the University of Greifswald, has been made professor of chemistry. Dr. Wachsmuth has been appointed docent in physics in the University of Göttingen, and Dr. Emil Knoblauch docent in botany in the University of Giessen.

Dr. ERNST BEYRICH, professor of geology and paleontology, died at Berlin on July 9 th at the age of 81 years.

Dr. Franz Reuleaux, for forty years professor of engineering in the Technical High School at Charlottenburg, has resigned.

\section{DISCUSSION AND CORRESPONDENCE.} THE PERSONAL EQUATION.

In the admirable heliometric triangulation of the cluster in Coma Berenices, by Dr. F. L. Chase, lately published by the Yale Observatory, the author has not noticed that the cluster is one which was photographed by Mr. Rutherfurd in 1870 and several years since; hence, material is already on record for the proper motions of the group. The cluster will furnish an unusual number of stars which can be observed for personal equation between bright and faint ones, a problem which is not without psychological as well as astronomical interest at the present time. It will be remembered that among very early studies in experimental psychology were those experiments conducted by 
Wundt in 1861, which resulted in his important discovery of the Zeitverschiebung, which takes place when the observer connects clock beats heard with the seen positions of a star in appaent motion through the field of the telescope. As this Zeitverschiebung may be either positive or negative, it offers an explanation of the abnormal personal equations (more than a second of time) which Bessel found to take plaee in his own case, as compared with Argelander and Wilhelm Struve. The variations of personal equation depending on the magnitudes of the stars can most readily be studied by the help of heliometric or photographic relative right ascensions such as are now in progress of publication. The Pleiades, Præsepe and Coma Berenices, as well as the clusters in other parts of the sky which have been photographed by Rutherfurd, deserve careful study by transit observers. The delay in reaction caused by the faintness of the stars is now pretty well recognized by astronomers when the chronograph is used, but there are indications of a similar delay in apperception when the eye and ear method is still retained. Astronomers need to pay especial attention to those magnitudes of stars which are near the point where the observation of transits begins to become difficult.

\section{T. H. SAFFORD.}

CINNABAR AND RUTILE IN MONTANA.

To the Editor of ScIence : I wish to call the attention of your readers to a new locality for cinnabar and rutile. Specimens were sent me from the placer works in the vicinity of Philipsburg, Montana, with the idea that they were hematite and emery. The cinnabar is in small rolled grains, quite pure, and the rutile in small prisms. Neither of these minerals are known to have been found in Montana before. I hope to obtain more definite information concerning the occurrence of these minerals later.

Michigan Mining School, M. E. WADSWORTH. Hovghton, Mich.

\section{PYGMY VILLAGES DISCOVERED IN THE INTERIOR} OF SURINAM, GUIANA.

To THE Editor of Science: Yesterday I received a letter from an American commer- cial explorer of Guiana, who had recently met there with villages of typical pygmies, who are not over 4 feet 8 inches in height, and have a 'brilliant reddish-yellow complexion.' They seem to have come from the head waters of the Orinoco, and to be numerous enough to finally settle the problem as to the existence of dwarf races in America. Humboldt heard rumors as to them, but was unduly skeptical. I hope to be able, at the approaching meeting of the American Association at Buffalo, to submit a full description by the explorer, of his interesting discovery.

Boston, Mass., July 29, 1896.

\section{R. G. Haliburton.}

\section{SCIENTIFIC LITERATURE.}

Sporozoenkunde. VAN WASIELEWSKI. Ein Leitfaden für Aerzte, Tierärzte und Zoologen. Mit 111 Abbildungen im Text. Jena (Verlag von Gustav Fischer). 1896. Pp. 162. M. 4. The specialist in parasitology is frequently asked by general zoologists and by physicians for a short comprehensive book, which, while not too technical and detailed, will serve as a general guide to a brief study of the Sporozoa. As a rule he recommends Balbiani's Les Sporozoaires (1884) and Bütschli's Protozoa, I. Bd., II. Abth. (1882), both of which are now rather old; Blanchard's Traité de Zool. méd., I., p. 32-68, Railliet's Traité de Zool. méd. et. agric., I., p. 122-160 (1893), and Braun's Die tierischen Parasiten des Menschen., pp. 47-106 (1895), which though excellent, do not cover the entire field; or possibly Pfeiffer's Die Protozoen als Krankheitserreger (1891) - a book which is very diffi-. cult to comprehend, and in which the line between fact and supposition is not always clearly drawn.

To this list of general works we can now add von Wasielewski's Sporozoenkunde which forms, in some respects, a very excellent compilation on these parasitic protozoa.

In a general introduction to the Sporozoa the author discusses their (1) distribution, (2) habitat, (3) form, (4) food and motion, (5) reproduction, (6) development, and (7) classification. Each group is then discussed in turn, and brief diagnoses of the more common genera and species are given. Next follows a valuable tabu- 